\title{
Dwellers in dens on sandy bottoms: Ecological and behavioural traits of Octopus vulgaris
}

\author{
Ángel Guerra ${ }^{1}$, Jorge Hernández-Urcera ${ }^{1}$, Manuel E. Garci ${ }^{1}$, Marta Sestelo ${ }^{2}$, \\ Marcos Regueira ${ }^{1}$, Ángel F. González ${ }^{1}$, Miguel Cabanellas-Reboredo ${ }^{3}$, \\ Matías Calvo-Manazza ${ }^{3}$, Beatriz Morales-Nin ${ }^{3}$
}

\begin{abstract}
${ }^{1}$ Instituto de Investigaciones Marinas, CSIC, Eduardo Cabello 6, 36208 Vigo, Spain. E-mail: angelguerra @iim.csic.es ${ }^{2}$ Departament de Matemàtiques, Universitat Autònoma de Barcelona, 08193 Bellaterra (Cerdanyola del Vallès), Spain. ${ }^{3}$ Instituto Mediterráneo de Estudios Avanzados (IMEDEA, CSIC-UIB), Departamento de Recursos Naturales, Esporles, Islas Baleares, Spain.
\end{abstract}

\begin{abstract}
Summary: Four visual censuses targeting Octopus vulgaris living in dens on sandy bottoms were carried out from June to October 2013 in the National Park of the Atlantic Galician Islands (NW Spain). Censuses were undertaken by scuba diving between 5 and $21 \mathrm{~m}$ depth in daytime. The total area swept was 13.75 ha. There were no significant differences between octopus presence in dens during open and closed fishing seasons. Depth had a significant negative relationship with occupancy. The average number of dens per $1000 \mathrm{~m}^{2}$ was $3.84 \pm 0.84$ in June and 3.89 in October. The area per den was $260 \mathrm{~m}^{2}$. Den number estimations varied between 1586 and 2057. The largest number of dens (76.5\%) was found between 5 and $10 \mathrm{~m}$ depth. Den distribution was clumped. No significant differences were found between octopus size classes (small, medium and large) and den diameter. Associate dens were observed. There were no significant differences in den diameter and shell types found around the middens. Many dens could be "permanent". Drilling bivalve shell behaviour is discussed. The surveyed area had around 1100 individuals, mainly small specimens. No significant differences were found between octopus size and depth. Substrate, den type and food abundance and availability (especially razors Ensis arcuatus) seem to be the main factors influencing dens and octopus density and distribution. Den availability does not appear to be a limiting factor in this case. Temperature, den availability, predators and fishing pressure influencing density and distribution are discussed. Rodas inlet may be a preferential habitat for $O$. vulgaris individuals ranging from 200 to $2000 \mathrm{~g}$, but especially small specimens $(\leq 1000 \mathrm{~g})$.
\end{abstract}

Keywords: den ecology; visual census; habitat selection; drilling behaviour; Octopus vulgaris; National Park of the Atlantic Galician Islands (NW Spain).

\section{Moradores de guaridas de fondos arenosos: rasgos ecológicos y de comportamiento de Octopus vulgaris}

Resumen: Entre junio y octubre de 2013 se realizaron cuatro censos visuales enfocados a estudiar el pulpo común Octopus vulgaris que mora en guaridas en fondos arenosos. Los censos se realizaron en la ensenada de Rodas, ubicada en el archipiélago de Cíes dentro del Parque Nacional de las Islas Atlánticas de Galicia (NO España). Dichos censos se efectuaron con buceo autónomo entre 5 y $21 \mathrm{~m}$ de profundidad y durante el día. El área total barrida fue de 13.75 ha. No se encontraron diferencias significativas entre la presencia de pulpos en las guaridas durante la temporada de veda y la de pesca. La profundidad tuvo una significación negativa en relación con el grado de ocupación. El promedio de guaridas por cada $1000 \mathrm{~m}^{2}$ fue de $3.84 \pm 0.84$ en junio y 3.89 en octubre. El área por guarida fue de $260 \mathrm{~m}^{2}$. El número estimado de guaridas varió ente 1586 y 2057. El mayor número de madrigueras $(76.5 \%)$ se encontró entre 5 y $10 \mathrm{~m}$ de profundidad. La distribución de las guaridas era agregada. No se hallaron diferencias significativas entre el diámetro de los refugios y el tamaño de los pulpos. Tampoco hubo diferencias significativas entre el diámetro de las guaridas y los tipos de conchas encontradas alrededor. Se observaron guaridas asociadas. Algunas podrían ser utilizadas por varias generaciones: "guaridas permanentes". Se discute el comportamiento de perforación de las conchas de moluscos bivalvos por parte de $O$. vulgaris. El área muestreada tenía alrededor de 1.100 individuos, principalmente pulpos pequeños. No se hallaron diferencias significativas entre el tamaño de los pulpos y la profundidad. El sustrato, el tipo de guarida y la abundancia y asequibilidad de alimento (Ensis arcutatus especialmente) parecen ser los factores más influyentes en la densidad y distribución de los pulpos y sus guaridas. La disponibilidad de guaridas no fue un factor limitante en este caso. Se discute la posible influencia de otros factores, como la temperatura del agua, depredadores, la disponibilidad de guaridas y la presión pesquera sobre la densidad y distribución de los pulpos. La ensenada de Rodas parece ser un hábitat preferencial para $O$. vulgaris de tamaños comprendidos entre 200 y $2000 \mathrm{~g}$, pero sobre todo de ejemplares pequeños $(\leq 1000 \mathrm{~g})$.

Palabras clave: ecología de guaridas; censos visuales; selección de hábitat; comportamiento de perforación; Octopus vulgaris; Parque Nacional de las Islas Atlánticas de Galicia (NO España).

Citation/Como citar este artículo: Guerra A., Hernández-Urcera J., Garci M.E., Sestelo M., Regueira M., González A.F., Cabanellas-Reboredo M., Calvo-Manazza M., Morales-Nin B. 2014. Dwellers in dens on sandy bottoms: Ecological and behavioural traits of Octopus vulgaris. Sci. Mar. 78(3): 405-414. doi: http://dx.doi.org/10.3989/scimar.04071.28F 
Editor: E. Macpherson.

Received: March 31, 2014. Accepted: June 5, 2014. Published: July 28, 2014.

Copyright: (C) 2014 CSIC. This is an open-access article distributed under the Creative Commons Attribution-Non Commercial Lisence (by-nc) Spain 3.0.

\section{INTRODUCTION}

The common octopus, Octopus vulgaris Cuvier 1797 , is an economically important resource throughout the Iberian Peninsula. Official average landings in Galicia (NW Spain) for the period 2010-2013 were 2984 t (www.pescadegalicia.com).

This mobile species is well adapted to living in different biotopes (sandy and muddy bottoms, rocks, coral reefs and seagrass) and it is an opportunistic carnivorous predator during adulthood, feeding mostly upon crabs, molluscs, polychaetes and bony fish (Mangold 1983). Like other octopus species, O. vulgaris modify their soft habitats by excavating dens and by accumulating midden piles of different materials, often prey remains (Mather 1991).

Focussing on assessment of preference at specific den location, Anderson et al. (2008) showed that while the population had a wide choice of prey items, the individual choices were much narrower, indicating that octopuses are specializing generalists. Furthermore, the ability of octopus, including $O$. vulgaris, to drill holes in mollusc shells is well known (Nixon and Boyle 1982; Nixon 1987; Nixon and Maconnachie 1988; Mather and Nixon 1990) and was found in juveniles $O$. vulgaris inhabiting Viños islet within the National Park of the Atlantic Islands of Galicia (NPAIG) (Guerra and Nixon 1987).

To avoid predation and competition, many octopuses select shelters where they remain most of the time, particularly during daylight (Mather 1988). In consequence, the characteristics of the bottom have been thought to be the main factor influencing their density and distribution patterns (Aronson 1991, Hanlon and Messenger 1996, Leite et al. 2009). Information about relative abundance, distribution pattern and biomass fluctuations in time and space are critical for understanding the ecology of any species (Kaiser et al. 2011) and for fishery management (Cochrane and Garcia 2009).

A number of physical and biotic factors may influence octopus spatial distribution and density of natural populations. Den availability and preference for edges were crucial in tropical reefs (Aronson 1986; Anderson 1997). Allocation of shells in which the octopus hid was found to be a key factor explaining the Octopus joubini's aggregate distribution in a subtropical ecosystem (Mather 1982). Substrate, kelp cover and shallow waters had a positive correlation for Enteroctopus dofleini (Scheel 2002). Den availability was also a limiting characteristic for octopus distribution (Altman 1967, Hartwick and Thorarinsson 1978, Mather 1982, Hartwick et al. 1984). Octopuses may exercise substantial choice in habitat and shelter, and often modify shelters to their satisfaction (Mather 1994). This home choice was documented for $O$. vulgaris living on soft bottoms in the Mediterranean Sea (Katsanevakis and Verriopolus 2004 a,b).

Other factors than habitat, such as seasonality (Hartwick et al. 1984, Iribarne 1991), reproduction (Iribarne, 1990), depth and sea water temperature (Katsanevakis and Verriopolus 2004a), and predator pressure and reproductive demand (Aronson 1986, Leite 2007, Huffard et al. 2008) were also essential, whereas prey availability was not essential to $O$. joubini and $E$. dofleini (Mather 1982, Scheel et al. 2007).

Some of these ecological and behavioural aspects of $O$. vulgaris were considered in the central-east Atlantic and the Mediterranean Sea from fishery databases and fishing surveys (Guerra 1981, Sánchez and Obarti 1993, Quetglas et al. 1998, Belcari et al. 2002, Tsangridis et al. 2002), and Moreno et al. (2014) found the essential habitats for pre-recruitment along the Portuguese coast. However, there are many features that cannot be investigated through fishing surveys requiring direct observations in the field (Mather 1991, Hanlon et al. 2008, Katsanevakis and Verriopolus 2004b). Moreover, the study of interactions of individuals and the use that mobile and intelligent benthic octopuses make of the natural environment can be drastically altered by the restrictions imposed by captivity conditions (Mather 1982).

The dynamics of habitat selection in octopus are complex and likely important to fisheries and marine communities (Mather 1993). Despite the commercial importance of $O$. vulgaris, studies on its distribution patterns, density and den ecology are practically nonexistent in the northeast Atlantic.

In order to understand some ecological and behavioural traits of $O$. vulgaris living in dens on soft bottoms of Rodas inlet (Cíes archipelago within the National Park) visual censuses were carried out. The site was selected because it has an unusual abundance of octopuses, which are intensely fished, and because it has a high abundance of dens (cefaparques.blogspot. com). Direct visual observation was chosen because it had already been used as an important tool for the study of these aspects in octopods (e.g. Mather 1991; Oosthuizen and Smale 2003; Hanlon et al. 2008; Leite et al. 2009), and because its impact is not harmful to the species and the environment. The main objectives of this work were: 1) to estimate density of $O$. vulgaris and 2) to test whether it has a non-random distribution, related mainly to substrate and body size.

\section{MATERIALS AND METHODS}

\section{Study area}

The Cíes archipelago is situated within the NPAIG, which is in the mouth of the Ría de Vigo (Fig. 1). The 


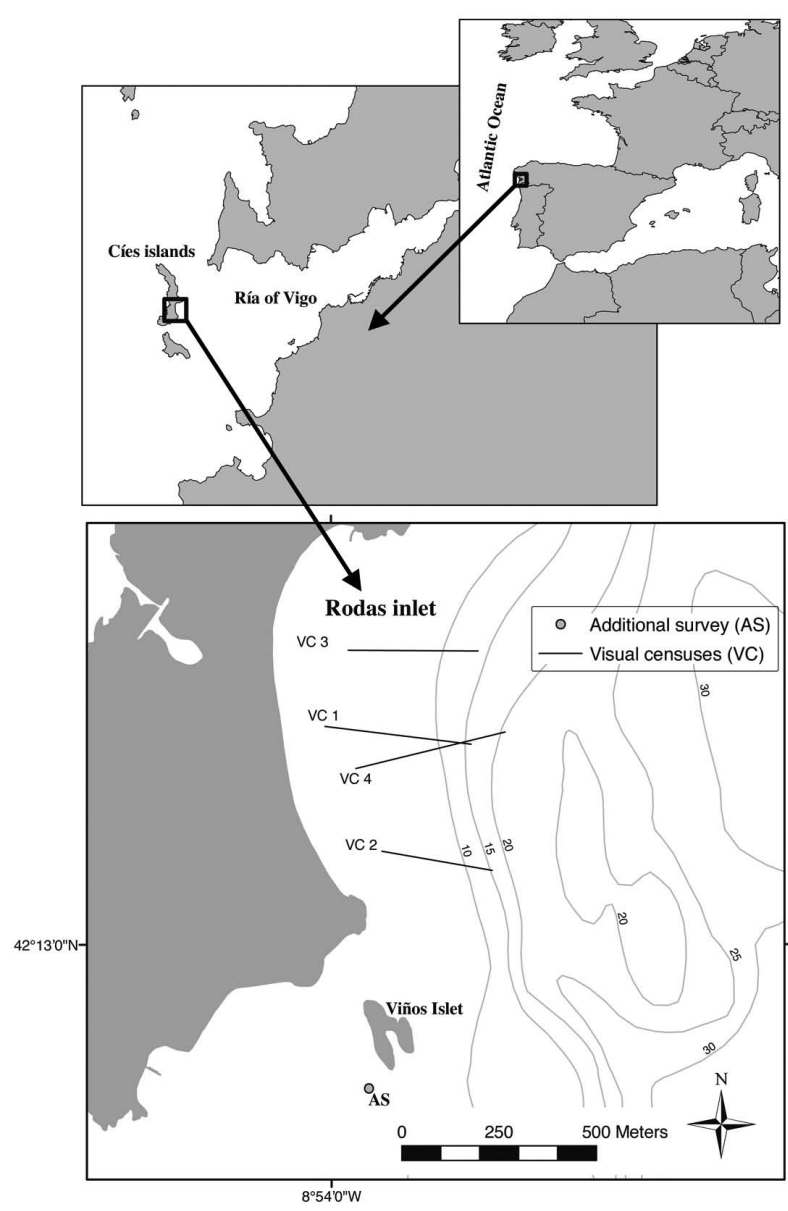

Fig. 1. - Map of the Rodas Inlet within the Cíes Islands (National Park of the Atlantic Islands of Galicia), showing location of visual censuses (VCs).
Table 1. - Visual survey data for $O$. vulgaris in the Rodas inlet. VC, visual census number; SA, swept area $\left(\mathrm{m}^{2}\right)$; D, average depth (m); $\mathrm{APD}$, area per den $\left(\mathrm{m}^{2}\right)$; OD, occupied dens; ARDO, average rate of occupancy $(\%)$; D/1000, mean number of dens per 1000 square meters

\begin{tabular}{ccccccc}
\hline VC & S A & D & APD & OD & ARDO & D/1000 \\
\hline 1 & 3330 & 11 & 302.73 & 10 & 90.91 & 3.30 \\
2 & 2910 & 14 & 207.86 & 11 & 78.57 & 4.81 \\
3 & 2350 & 8 & 293.75 & 7 & 87.50 & 3.40 \\
4 & 5145 & 20 & 257.25 & 14 & 70 & 3.89 \\
\hline
\end{tabular}

area of the marine realm of the Cíes is 2658 ha. Observations were carried out in the Rodas inlet, located on the inner side between the northern and central islands of the Cíes archipelago (Fig. 1). The sandy bottom of this inlet is between 5 and $21 \mathrm{~m}$ deep and has an area of 30 ha.

The NPAIG is located on the northern boundary of the Iberian upwelling system. Coastal winds at these latitudes ( 42 to $44^{\circ} \mathrm{N}$ ) are seasonal; northerly winds prevail from March-April to September-October, promoting coastal upwelling, and southerly winds predominate the rest of the year. However, more than $70 \%$ of the total variability in coastal winds occurs in periods of less than one month, so the upwelling season appears as a succession of wind-stress episodes separated by calm episodes, with a frequency of 10 to 20 days (Álvarez-Salgado et al. 2003), similar to other coastal upwelling systems at comparable latitudes (Hill et al. 1998).

\section{Visual censuses}

Three visual censuses (VC 1-3) were conducted in June 2013 in the north, centre and south of Rodas inlet, when the $O$. vulgaris fishery was closed (from

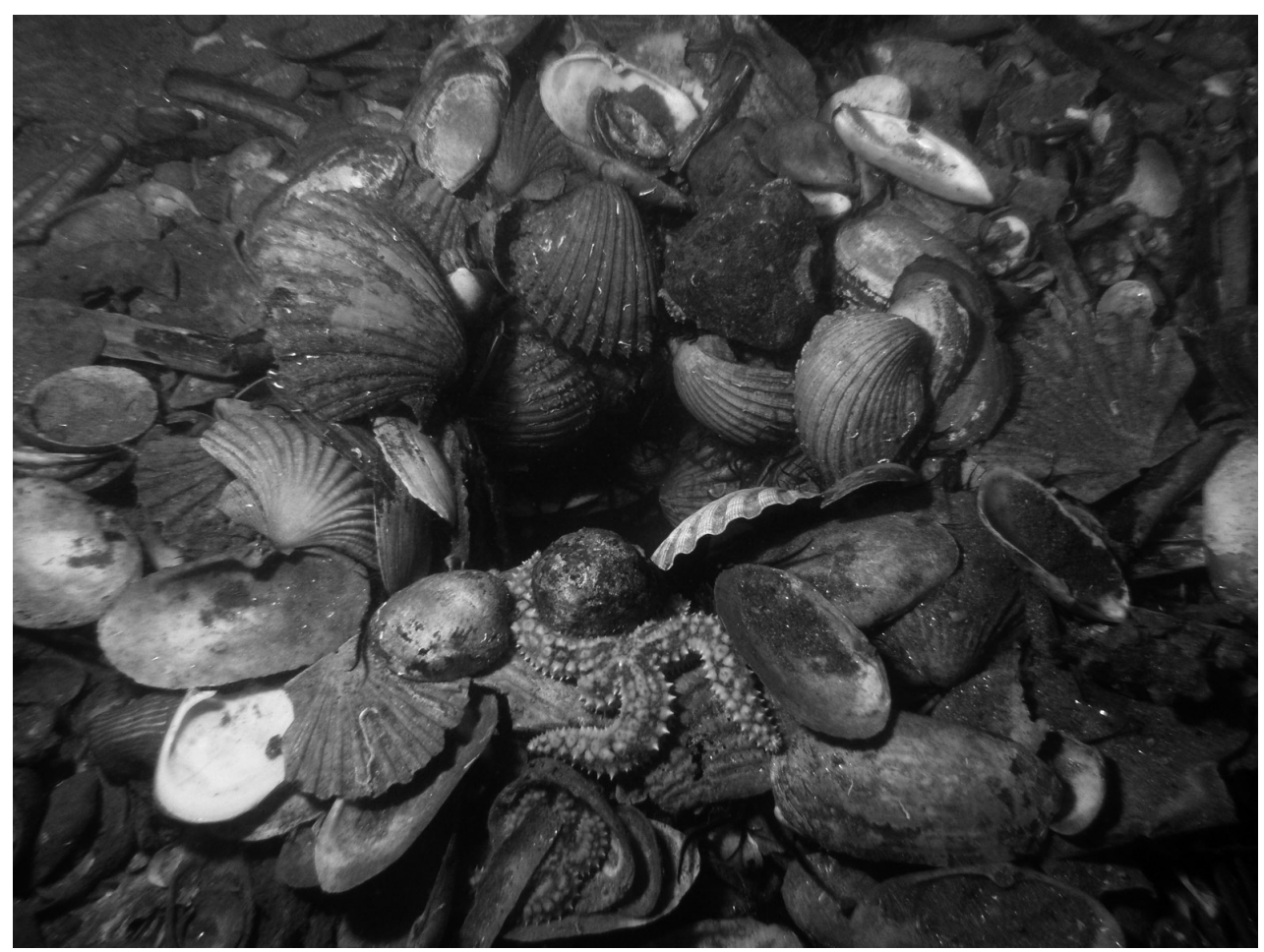

Fig. 2. - One of the $O$. vulgaris dens found on the sandy bottom of the Rodas inlet (NAPAIG), showing the central hole and the midden. 
17 May to 1 July). A fourth one (VC 4) was carried out in October 2013 in the central zone of Rodas inlet after the opening of the fishing octopus season. The visual censuses were made in daytime. The start and end points of each visual census were established by GPS, and then marked with buoys at the surface. A guide rope between the two points was deployed. Depth varied from 5 to $21 \mathrm{~m}$ (Table 1). Four divers worked simultaneously in each census and they were spread laterally at a fixed distance along a rope. The following data were recorded:

i) Depth and sea bottom temperature, recorded with a diving computer.

ii) Salinity recorded with conductivity, temperature, and depth (CTD) sensors.

iii) Presence/absence of specimen in the den.

iv) Octopus size class according to the following scale: size 1 (small), <1000 g total body weight (BW); size 2 (medium), 1001-2000 g BW; size 3 (large), $>2001 \mathrm{~g} \mathrm{BW}$.

v) Species present in the den.

vi) Den diameter.

vii) Type of den: a) hole, when the animal digs a vertical hole in the soft sediment and reinforces the inner part with shells and other solid materials (Fig. 2), generally bringing solid materials around the rim of the hole; b) stone, when the octopus uses a stone and digs a hole underneath; c) empty shell and/or crab carapace; and d) human origin.

viii) Observations: isolated or joined dens, presence of scavengers.

The $O$. vulgaris size classes were picked for three reasons: i) the experienced professional divers were able to categorize an octopus as belonging to one of the three size classes; ii) the legal size in the Galician fishing grounds for this species is $1000 \mathrm{~g}$, and iii) octopuses are split into medium and large size classes for the auction at the fishing market (Xunta de Galicia 2006, DOGA 2012).

A random sample of the objects found around the octopus shelter was collected in six dens. A Sony videocamera HDR-cx700 recorded every visual census.

In order to test whether or not the bivalve shells in dens had drilled holes, an additional survey (AS) was undertaken by two divers at the Viños islet (Fig. 1) on November 14, 2013. All shells present in four dens of octopuses with a $500 \mathrm{~g} \mathrm{BW}$ were collected in this survey. They were measured and examined in the laboratory.

\section{Statistics}

Due to the non-normality of the data, a KruskalWallis test (Zar 2010) was applied in order to check differences in den diameter and depth of the dens in relation to the shell types of the species used to build the dens; and diameter and depth of the dens in relation to the size of the octopuses found.

A Generalized Linear Model (McCullagh-Nelder 1989) was fitted with presence/absence of octopus in the den as the response variable to study the den occupancy. Fishing season (open/closed) and depth were
Table 2. $-O$. vulgaris den data in the Rodas inlet. VC, visual census number; DR, depth range (m); DF, number of dens found; ARDO, average rate of occupancy $(\%)$; DDA, den diameter average $(\mathrm{cm})$; MSBT, mean sea bottom temperature $\left({ }^{\circ} \mathrm{C}\right)$; SD, standard deviation

\begin{tabular}{cccccc}
\hline VC & DR & DF & ARDO & DDA \pm SD & MSBT \pm SD \\
\hline \multirow{2}{*}{$1,2,3$} & $5.0-10.0$ & 27 & 92.6 & $19.4 \pm 8.61$ & $14.4 \pm 0.5$ \\
& $10.0-15.0$ & 6 & 50 & $14.83 \pm 6.24$ & $14.21 \pm 0.4$ \\
\hline \multirow{2}{*}{4} & $5.0-10.0$ & 9 & 100 & $17.44 \pm 5.08$ & $18 \pm 0$ \\
& $10.0-15.0$ & 6 & 50 & $16.83 \pm 5.81$ & $17.82 \pm 0.4$ \\
& $15.0-21.0$ & 5 & 40 & $17.6 \pm 3.51$ & $16.44 \pm 0.54$ \\
\hline
\end{tabular}

Table 3. - Octopus vulgaris size distribution by depth in the Rodas inlet. VC, visual census number; DR, depth range (m); OSC, octopus size data class (S, small; M, medium; L, large); N, number of octopus found; \%, percentage of octopuses by depth

\begin{tabular}{|c|c|c|c|c|c|c|c|c|c|}
\hline \multirow{2}{*}{$\mathrm{VC}$} & \multirow{2}{*}{ DR } & \multicolumn{6}{|c|}{ OSC } & \multicolumn{2}{|c|}{ Total } \\
\hline & & $\mathrm{N}$ & $\%$ & $\mathrm{~N}$ & $\%$ & $\mathrm{~N}$ & $\%$ & $\mathrm{~N}$ & $\%$ \\
\hline \multirow[t]{2}{*}{$1,2,3$} & $5.0-10.0$ & 13 & 52 & 8 & 32 & 4 & 16 & 25 & 89.28 \\
\hline & $10.0-15.0$ & 3 & 100 & & & & & 3 & 10.71 \\
\hline \multirow{3}{*}{4} & $5.0-10.0$ & 7 & 77.8 & 1 & 11.1 & 1 & 11.1 & 9 & 64.28 \\
\hline & $10.0-15.0$ & 1 & 33.3 & & & 2 & 66.7 & 3 & 21.43 \\
\hline & $15.0-21.0$ & 2 & 100 & & & & & 2 & 14.28 \\
\hline
\end{tabular}

used as discrete and continuous covariates, respectively. Likelihood ratio tests, based on the deviance, were applied to test the effect of each covariate in the model.

To ascertain whether the distribution of the octopus dens in the sample areas was random, we employed the method of Morisita (1959), using densities estimated from the four visual censuses.

\section{RESULTS}

The total area swept in the visual censuses was 13.735 ha (Table 1$)$. The surveyed area during the closed and open fishing seasons was $5150 \mathrm{~m}^{2}$ and 2850 $\mathrm{m}^{2}$, respectively. The mean rate of occupancy during the octopus closed season in June (VC 1-3) was $85.6 \%$ (range $78.57 \%-90.91 \%$ ), whereas it was $70.0 \%$ when the creel fishery targeting octopus was open in October (VC 4). The presence of $O$. vulgaris in the dens was not significantly different ( $\mathrm{p}$-value $=0.692$ ) between the samples taken during the closed and open fishing seasons. However, depth showed a significant negative relationship with occupancy (Fig. 3). The value obtained for the Morisita method $\left(\mathrm{I}_{\delta}=1.77\right)$ indicated that animals occupying dens (Table 1) were not randomly dispersed but aggregated.

The mean number and the standard deviation of dens per $1000 \mathrm{~m}^{2}$ was $3.84 \pm 0.84$ in June, whereas it was 3.89 in October (Table 1). Consequently, there was a den each $260 \mathrm{~m}^{2}$ (range 208-303). Den number estimation in the area surveyed varied between 1586 and 2050. Considering the mean den occupancy $(\mathrm{ARDO}=85.7 \%$; Table 1), the number of specimens in the Rodas inlet ( 5 to $21 \mathrm{~m}$ depth) would be 1015 , which represents 3.38 individuals per $1000 \mathrm{~m}^{2}$.

The total number of dens found was 53 (Table $2)$. The largest number of dens $(76.5 \%)$ was found at depths ranging from 5 to $10 \mathrm{~m}$. The value of the Morisita index estimated considering the number of dens within the range $5-15 \mathrm{~m}$ depth $\left(\mathrm{I}_{\delta}=1.44\right)$ showed that dens had a crumpled distribution. 

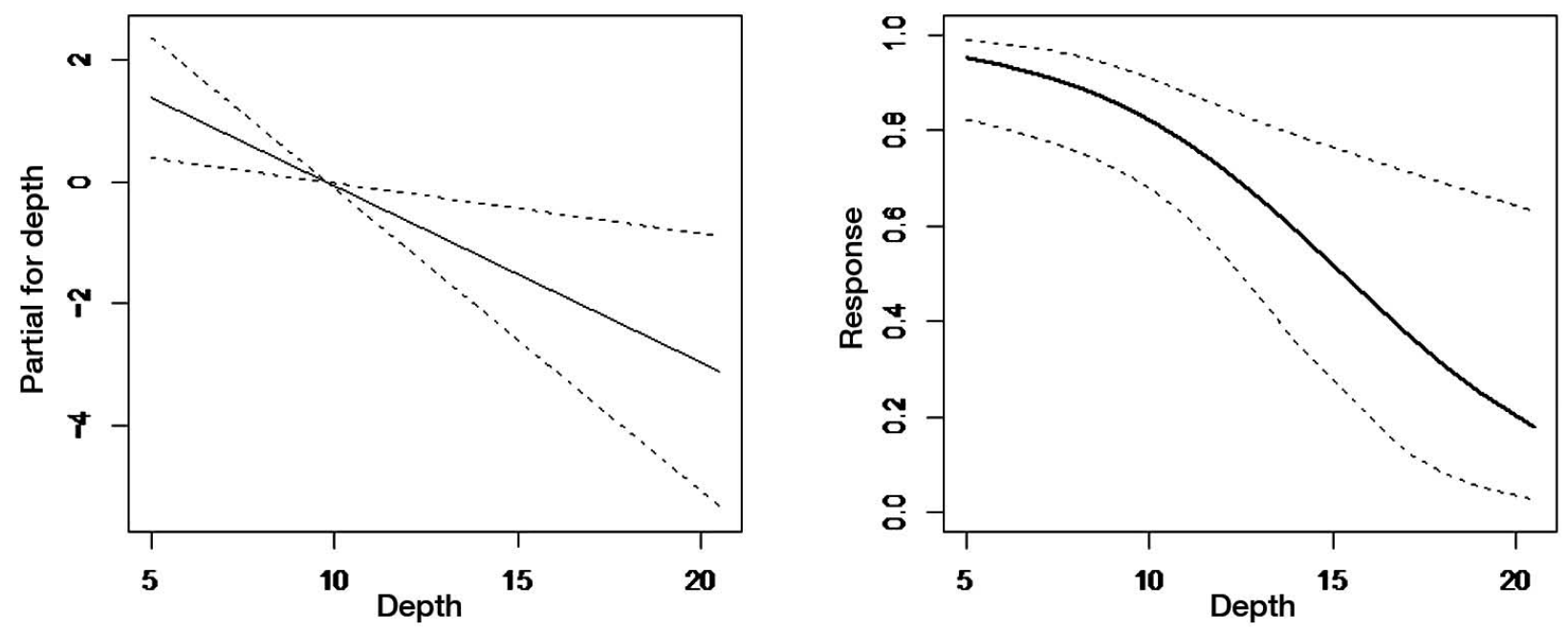

Fig. 3. - Left panel: partial effect (solid line) with the 95\% confidence interval (broken lines) of the covariate depth on the presence/absence of $O$. vulgaris in dens. The results are reported on the scale of the linear predictor. Right panel: prediction of the probability of den occupancy of $O$. vulgaris.

Table 2 also shows the mean and standard deviation of the diameters of 33 dens found in VCs 1-3 for June by depth range and occupancy rate by depth. The same data are given to 20 dens from VC 4. No significant differences were found for octopus size in relation to den diameter $(\mathrm{p}=0.129)$ within the three size classes.

Associated dens were observed: two were coupled, one was composed of two crevices, and the third was composed of three holes. Scavengers (serpent and sea stars, sea urchins and nettle dog whelks) were found in all dens found at the deeper depth range $(15-21 \mathrm{~m})$.

Table 3 indicates the size classes in total number and percentage of octopuses by depth range. Forty-two individuals were found in total: $66.7 \%$ between 5 and $10 \mathrm{~m}$ depth, $28.6 \%$ from 10 to $15 \mathrm{~m}$, and $4.7 \%$ between
15 and $21 \mathrm{~m}$. Small octopuses (Size class 1) were found at all surveyed depths: $52 \%$ between 5 and $10 \mathrm{~m}, 40 \%$ between 10 and $15 \mathrm{~m}$ and $8 \%$ in deeper waters. Medium octopuses were only present in shallower waters, while large individuals were found from 5 to $15 \mathrm{~m}$ depth, being more abundant (35.7\% of the total) in the shallowest depth range. No significant differences were found for octopus size in relation to depth $(\mathrm{p}=0.146)$.

Table 4 summarizes the most abundant bivalve species found in the dens during VCs 1-4. None of the bivalve shells examined was drilled. There were no significant differences in den diameter for the different shell types found $(\mathrm{p}=0.494)$. By contrast, in relation to the depth variable, significant differences were observed between the shell types $(p<0.001)$, showing

Table 4. - Data to bivalve species found in $O$. vulgaris middens in Rods inlet per visual census 1-4 (VCs 1-4). BS, bivalve species (1, Ensis arcuatus; 2, Glycimeris glycimeris; 3, Lutraria lutraria; 4, Pecten maximus; 5, Venerupis spp.; 6, Mytillus galloprovincialis); VC, visual census number; D, depth $(\mathrm{m})$; DD, den diameter $(\mathrm{cm})$

\begin{tabular}{|c|c|c|c|c|c|c|c|c|c|c|c|c|c|c|}
\hline \multicolumn{3}{|c|}{ VC 1} & \multicolumn{3}{|c|}{ VC 2} & \multicolumn{3}{|c|}{ VC 3} & \multicolumn{6}{|c|}{ VC 4} \\
\hline$\overline{B S}$ & $\mathrm{D}$ & DD & $\mathrm{BS}$ & $\mathrm{D}$ & DD & $\mathrm{BS}$ & $\mathrm{D}$ & DD & $\mathrm{BS}$ & $\mathrm{D}$ & DD & $\mathrm{BS}$ & $\mathrm{D}$ & $\mathrm{DD}$ \\
\hline 4 & 13.0 & 15 & 4 & 13.6 & 18 & 1 & 9.2 & 20 & 4 & 20.5 & 16 & 4 & 9.9 & 14 \\
\hline 1 & 13.0 & 15 & 1 & 13.6 & 18 & 1 & 8.6 & 15 & 4 & 19.0 & 14 & 3 & 9.9 & 14 \\
\hline 1 & 10.3 & 4 & 1 & 11.7 & 14 & 4 & 8.5 & 15 & 3 & 19.0 & 14 & 6 & 9.9 & 14 \\
\hline 4 & 9.8 & 14 & 1 & 10.7 & 23 & 1 & 8.5 & 15 & 4 & 19.0 & 19 & 4 & 9.6 & 21 \\
\hline 4 & 9.8 & 14 & 1 & 10.2 & 15 & 4 & 8.2 & 13 & 5 & 19.0 & 19 & 3 & 9.6 & 21 \\
\hline 4 & 9.8 & 14 & 1 & 9.7 & 20 & 4 & 7.3 & 17 & 1 & 19.0 & 19 & 4 & 9.4 & 17 \\
\hline 4 & 9.1 & 30 & 1 & 9.1 & 20 & 1 & 7.3 & 17 & 1 & 18.0 & 16 & 3 & 9.4 & 17 \\
\hline 1 & 7.3 & 14 & 1 & 8.9 & 18 & 2 & 7.3 & 17 & 4 & 17.3 & 23 & 4 & 9.4 & 20 \\
\hline 1 & 5.8 & 15 & 2 & 8.9 & 18 & 2 & 5.9 & 25 & 3 & 17.3 & 23 & 3 & 9.4 & 20 \\
\hline 1 & 5.3 & 13 & 1 & 8.7 & 40 & 3 & 5.9 & 25 & 4 & 14.5 & 11 & 5 & 9.4 & 20 \\
\hline 3 & 5.3 & 13 & 2 & 8.7 & 40 & 1 & 5.6 & 40 & 3 & 14.5 & 11 & 4 & 9.0 & 25 \\
\hline 1 & 5.2 & 8 & 1 & 8.3 & 16 & 2 & 5.6 & 40 & 5 & 14.5 & 11 & 3 & 9.0 & 25 \\
\hline 1 & 5.0 & 16 & 3 & 8.3 & 16 & & & & 4 & 13.1 & 23 & 4 & 8.0 & 17 \\
\hline 3 & 5.0 & 16 & 2 & 8.3 & 16 & & & & 3 & 13.1 & 23 & 3 & 8.0 & 17 \\
\hline 4 & 13.0 & 15 & 1 & 8.3 & 18 & & & & 1 & 13.1 & 23 & 4 & 7.4 & 22 \\
\hline 1 & 13.0 & 15 & 3 & 8.3 & 18 & & & & 6 & 13.1 & 23 & 3 & 7.4 & 22 \\
\hline 1 & 10.3 & 4 & 2 & 8.3 & 18 & & & & 5 & 12.6 & 13 & 1 & 7.4 & 22 \\
\hline 4 & 9.8 & 14 & 1 & 8.2 & 23 & & & & 6 & 12.6 & 13 & 1 & 5.2 & 11 \\
\hline 4 & 9.8 & 14 & 2 & 8.2 & 23 & & & & 4 & 11.5 & 23 & 1 & 5.0 & 11 \\
\hline 4 & 9.8 & 14 & 1 & 8.0 & 11 & & & & 3 & 11.5 & 23 & & & \\
\hline 4 & 9.1 & 30 & 3 & 8.0 & 11 & & & & 1 & 11.5 & 23 & & & \\
\hline 1 & 7.3 & 14 & 2 & 8.0 & 11 & & & & 4 & 11.0 & 20 & & & \\
\hline \multirow[t]{3}{*}{1} & 5.8 & 15 & 1 & 7.9 & 17 & & & & 3 & 11.0 & 20 & & & \\
\hline & & & 2 & 7.9 & 17 & & & & 6 & 10.6 & 11 & & & \\
\hline & & & 2 & 7.4 & 18 & & & & 3 & 10.6 & 11 & & & \\
\hline
\end{tabular}




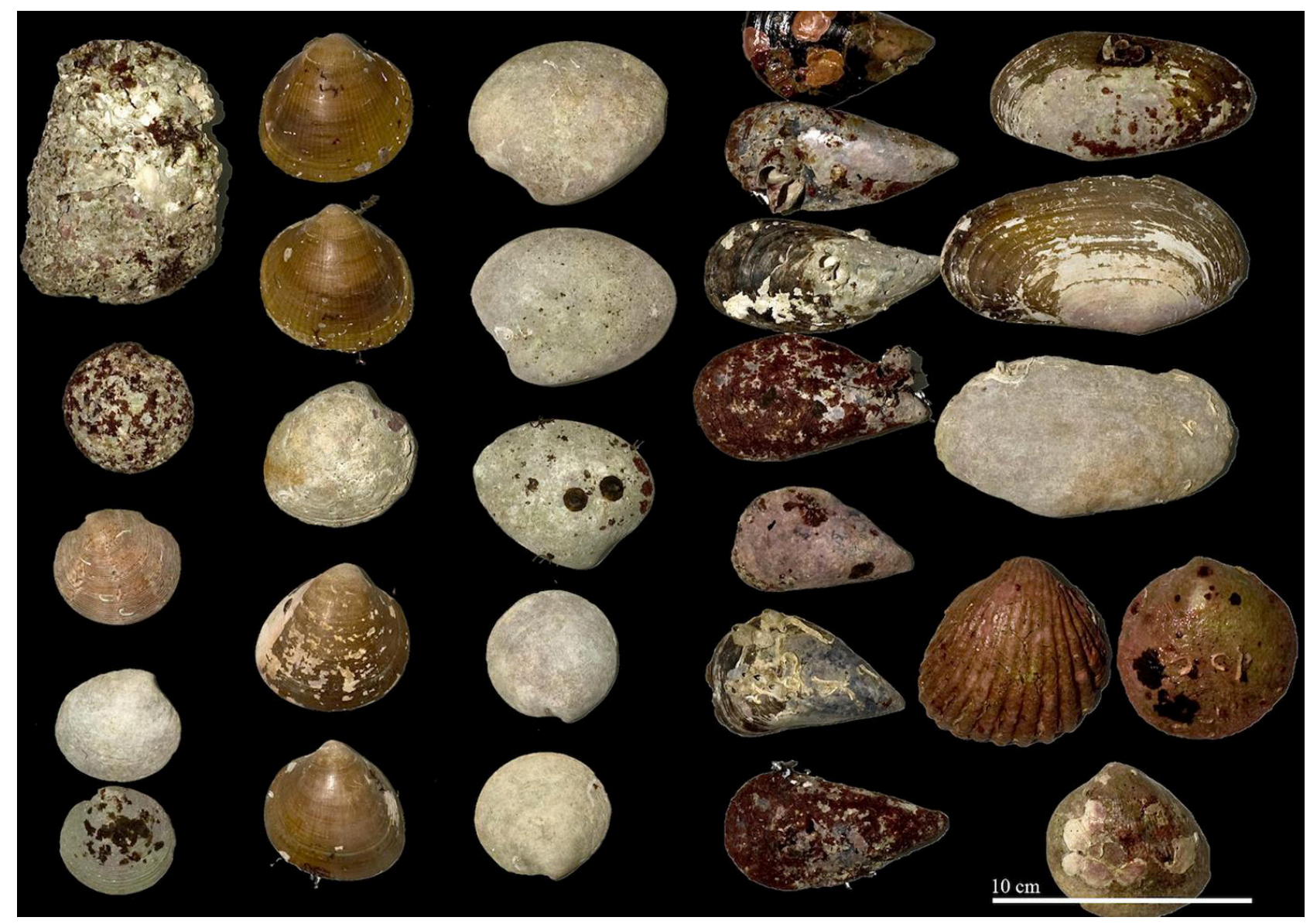

Fig. 4. - Samples of very long established bivalve shells found in one of the $O$. vulgaris midden piles located on the sandy bottom of the Rodas inlet (NAPAIG).

dens with Ensis arcuatus and Glycimeris glycimeris at lower depth.

Four characteristics of $55 \%$ of the observed dens in the soft bottom of the Rodas inlet suggested that these constructions could be "permanent", that is, they could be used for several octopus generations. These characteristics were i) holes narrow and deep and their inner walls reinforced with shells; ii) rim of the dens very long-established, showing encrusted shell-boring polychaetes (Polydora spp.), bryozoans and honeycomb structures produced by the sponge Cliona celata (Fig. $4)$; iii) very large and well-built dens occupied by small octopuses; and iv) the rim of dens around three times the diameter of the hole.

\section{DISCUSSION}

The Rodas inlet has resulted to be a suitable area for O. vulgaris ranging from 200 to $2000 \mathrm{~g}$, but especially for small individuals (76 and 73\% in VCs 1-3 and VC 4 , respectively; Table 3 ). The Rodas inlet is greatly influenced by a seasonal upwelling and is therefore a highly productive marine realm (Álvarez-Salgado et al. 2002). Species such as $O$. vulgaris may take advantage of these productive ecosystems by living there, as has occurred in other areas of the NW Atlantic Ocean (Moreno et al. 2014). Sea bottom temperature (SBT) and sea bottom salinity (SBS) were the main environ- mental variables limiting pre-recruit or sub-adult aggregation in the eastern Mediterranean (Katsanevakis and Verriopoulos 2004a), the Mediterranean Sea and the eastern Atlantic (Hermosilla et al. 2011) as well as in Portuguese waters (Moreno et al. 2014). O. vulgaris is most often found in water with a SBT warmer than $10^{\circ} \mathrm{C}$ and cooler than $30^{\circ} \mathrm{C}$ and a salinity ranging from 32 to 40 (Mangold 1983). Both parameters were within these ranges during the surveys in the Rodas inlet (Table 2).

The number of specimens in the Rodas inlet from 5 to $21 \mathrm{~m}$ depth (1015) represents 3.38 individuals per $1000 \mathrm{~m}^{2}$. This density is 6.8 times higher than the highest densities estimated by Guerra (1981), Fonseca and Campos (2002), Belcari et al. (2002) and Katsanevakis and Verriopoulus (2004a) in different geographic areas. Moreover, additional observations during these VCs also showed that there were animals dwelling in deeper waters (down to $40 \mathrm{~m}$ depth) in the zone. This was also the case in several Mediterranean areas, where the highest abundances of $O$. vulgaris of comparable sizes were found within the depth range of 10-50 m (Belcari et al. 2002). Similarly, octopus densities were higher at depths of 20-40 m than further offshore on the NW African coasts (Faraj and Bez 2007).

O. vulgaris densities found in the Rodas inlet were within the range found for $O$. insularis in Fernando de Noronha Archipelago, Brazil. However, they were 
nearly three times the highest densities found for Enteroctopus dofleini in Prince William Sound, Alaska. However, these comparisons should be taken with caution because very different substrates and seasons were considered in the case of $O$. insularis and E. dofleini, whereas for $O$. vulgaris these two variables were not considered.

Despite its restrictions, the methodology used in this study pointed to an aggregate distribution of $O$. vulgaris. Our evidence supports the same crumpled distribution found for the species in central-eastern Africa (Guerra 1981), southeastern South Africa (Oosthuizen and Smale 2003), and the eastern Mediterranean (Katsenavakis and Verriopolou 2004a). The individuals need hard structures on soft substrates or penetrable areas in hard substrates. In the Rodas inlet $O$. vulgaris find bivalve shells in abundance, and also relatively hard but penetrable substrates (maërl) among a general scenario mainly made up of open sand of different-sized grains, which could be the key factor explaining the aggregate distribution found. The influence of small but significant differences in the hardness of the substrate is an aspect that should be studied more seriously. A crumpled distribution was also found in $O$. joubini in St Joseph Bay, Florida, which is shallow and has a mixture of open sand and Thalassa grass beds. In that case, the factors that may have influenced octopus distribution were the substrate of sand and grass, and shells in which to hide because $O$. joubini does not burrow in sand (Mather 1982). Scheel (2002) observed a positive association between $E$. dofleini density and substrate and shallow waters (up to $5 \mathrm{~m}$ depth) in Alaska. Grass beds cannot explain the $O$. vulgaris aggregate distribution found at the Rodas inlet because it is composed exclusively of sandy bottoms and there are no shells in which to hide. In our long experience diving in the Cíes archipelago we have only observed this behaviour in juveniles octopus larger than 200 grams.

The den type was also an important factor for $O$. insularis, especially for the smaller ones (Leite et al. 2009). Similarly to O. insularis, juveniles of $O$. vulgar$i s$ generally occupied holes sunk perpendicular into the substrate, while large-sized specimens excavated dens beneath rocks and ledges. However, this behaviour was not observed in the Rodas inlet, and both juveniles and large octopuses were found in dens of different configuration built away from rocks in open sand substrate or maërl at different depths. What we found were den modifications by octopuses, such as removing sand, shingles and bivalve shells and placing items to block the aperture, as observed by Mather (1994).

We indicate herein, for the first time in $O$. vulgaris in the wild, that some old and well-built dens on a soft bottom of the Rodas inlet can be used successively by several generations of octopuses, which is why we call them "permanent". Their main characteristics are addressed in the results section. An old study by Hartwick and Thorarinssson (1978) on E. dofleini and a new one by Godfrey-Smith and Lawrence (2012) on O. tetricus suggest that this is very likely in a specific type of habitat. Den physical modifications by octopuses during long-term occupation, called "ecosystem engineering" by the last two authors, can be quite impressive, mostly involving handling of shells brought in during foraging. And it can be hypothesized that they could in turn result in higher densities being viable at the site.

The availability of shelters can be also a limiting factor for octopus distribution, as several studies of different species have described home choice and suggested characteristics used in selection of hiding places (Mather 1982, Altman 1967, Katsenevakis and Verriopoulos 2004b). However, dens do not appear to be limiting for E. dofleini in the eastern Pacific (Hartwick et al. 1984). The failure of octopus size to vary with den size, in contrast with the findings of Mather (1993), does suggest a limitation of den availability to $O$. vulgaris in the Rodas inlet. However, this aspect should be investigated more carefully because four surveys that do not target this specific facet are insufficient.

Environmental factors also influenced octopus density and distribution. A significant relationship of $O$. insularis size and depth was found by Leite et al. (2009). However, this was not the case for O. vulgaris in the Rodas inlet.

Temperature can also be a factor influencing octopus density and distribution. Smaller O. insularis prefer warmer temperatures than larger ones (Leite et al. 2009), perhaps in order to promote faster growth and thus shorten the period during which they are more vulnerable to predation, as observed by Katsanevakis and Verriopoulus (2004a) in O. vulgaris from the Mediterranean. This association between temperature and density and/or distribution was not investigated in the present study. However, estuaries like the Ría de Vigo are complex and very dynamic systems; their physical, chemical and biological properties show a sharp distributional gradient and large temporal variability of the meteorological factors that operate through an increase in the estuarine residual circulation. For this reason, SBT can change quite drastically in short time periods (Nogueira et al. 1997). It does not seem a very efficient strategy to subordinate octopus distribution to a factor (temperature) that can be very variable from week to week, provided that this factor does not go beyond the tolerance limits of the species, which it does not in any of the oceanographic situations that the ecosystem goes through in an annual cycle (Nogueria et al. 1997).

Another possibility is that predation pressure limits the distribution of very small octopuses (Aronson 1986). The main potential predators of $O$. vulgaris at Cíes archipelago are dolphins (Delphinus delphis and Turpsios truncatus) (López et al. 2004). Murray eel (Muraena helena), conger (Conger conger), sea bass (Dicentrarchus labrax) and some shark species (Rodríguez-Solorzano et al. 1983). Dolphins visit the inlet very infrequently because a marina for sports boats has been built (López et al. 2004). Murray eel, conger and shark species that can potentially prey upon octopus (Mustelus mustelus and/or Galeorhinus galeus) are not usually found on the sandy bottoms and shallow waters of the Rodas inlet (Garci and Hernández-Urcera, data not shown.). Adult sea bass in the northeastern Atlantic primarily target small pelagic fish, most notably mackerel (Scomber scombrus), scads (Trachurus 
spp.), anchovy (Engraulis encrasicolus), and sardine (Sardina pilchardus) (Spitz et al. 2013). Therefore, we consider that predation pressure by natural octopus predators at that site is not a main factor limiting their density and distribution. Nevertheless, fishing pressure can be a key factor in both the density and the size of the octopus we found in our surveys, for at least three reasons: 1) there was a relatively high discrepancy between the number of available dens (1586-2050) in the area and the number of individuals (1115), which were mainly of small size; 2) during the time when fishing is allowed (all year except in the quarter from June to September) the exploitation rate is very high around the Cíes archipelago (Ourens et al. 2010); and 3) the current law does not allow marketing of octopus under one kilogram (DOGA 2012), which, supposedly, are returned still alive to the sea if captured. Does that mean that $O$. vulgaris in the Rodas inlet is overexploited? This is an essential aspect of the management of the species in the whole Cíes archipelago that needs to be studied with more information. Oosthuizen and Smale (2003) suggested that the combined exploitation of inner and sub-tidal areas could be detrimental to the $O$. vulgaris stock in the temperate southeastern South Africa, as overexploitation of one area will impact on the other.

The patchy distribution of $O$. vulgaris in the Rodas inlet could be influenced by food. Vincent et al (1998) suggested that selection of habitats within the intertidal may be influenced by prey abundance in E. dofelini. As occurred in other octopus species (Anderson et al. 2008; Leite et al. 2009), O. vulgaris is able to prey upon a high variety of prey items (Nixon 1987). However, in some situations the common octopus feeds mostly on bivalve molluscs (Nixon 1987 and Boyle and Rodhouse 2005 for reviews). A similar diet was found in its twin species, O. mimus, in the northern Pacific (Cortez et al. 1995). This seems to be the case of the Rodas inlet, where bivalves are very abundant and available (Ourens et al. 2010). In addition to our direct observations, this finding is supported by the fact that a commercial fishery for razor fish (Ensis arcuatus) carried out by a restricted and low number of divers was developed there recently (64 t per year from 2010 to 2013; www. pescadegalicia. com). Moreover, scallops and clams, which were commercially exploited in specifics zones of the inlet several years ago, have significantly declined in recent years (www.pescadegalicia. com). The high abundance of bivalve shells collected in the extended middens of $O$. vulgaris is certainly a clue as to prey species. However, there are several challenges to using the remains of food items outside the dens, as pointed out by Anderson et al. (2008). Bivalve shells can be moved by currents or waves (Mather 1991), or biotic factors (Hartwick and Thorarissson 1978), and the octopus may push shells away from the den to reduce their visibility to possible predators, or carry them to protect and/or construct their middens (Ambrose 1982). We observed several foraging strategies and even a cannibalistic behaviour in the Cíes archipelago (Hernández-Urcera et al. 2014) but very few gastropod and crabs remains in the octopus middens in the Rodas inlet. The preference for bivalves shown by $O$. vulgaris at this site is probably related to two factors: 1) the highly efficient and well-established exploitation targeting crustaceans (www.pescadegalicia.com), and 2) the positive energetic balance obtained by predation of abundant and easily available bivalves, mainly razors (McQuaid 1994).

Techniques for penetrating hard-shelled prey are varied (Fiorito and Gherardib 1999, Anderson and Mather 2007). When the initial pulling method proves rapidly to be inefficient, octopus did not give up but started to drill. This procedure has been described in several octopus species, including O. vulgaris (Nixon and Boyle 1982, Guerra and Nixon 1987, Nixon and Maconnachie 1988, Mather and Nixon 1990). The interesting finding in the present study is that small octopuses $(>500 \mathrm{~g})$ examined by Guerra and Nixon (1987) in Viños islet (with the National Park) showed drilled gastropod bivalve mollusc shells in their dens. However, drilled bivalve shells were not found in the material collected in six dens from the Rodas inlet (VCs 1-4) 27 years later. In the old observation, drill holes were always in thick shells, while in the recent one remains of razor clams (Ensis arcuatus) and clams (Chamelea sp.), mainly found outside the middens, were not drilled. These findings suggest that the present abundance of thin and less resistant bivalve shells in the Viños islet could make a bivalve meal totally accessible by pulling apart shells instead of drilling them, as may be occurring in the Rodas inlet. Such "cultural" differences demonstrate that feeding programmes in octopods are flexible and reinforce the evidence demonstrating that the ability to learn, so characteristic of these animals, benefits the species and ensures survival (Scheel et al. 2007, Anderson et al. 2008, Leite et al 2009).

Visual censuses in the Rodas inlet also showed double and triple dens occupied simultaneously. This observation raises the question of whether $O$. vulgaris is totally intolerant to the nearby presence of conspecifics or, on the contrary, it is tolerant to a certain degree of crowding. Except Eledone moschata (Mather 1985), benthic octopuses are typically known as solitary animals (Guerra 1981, Boal 2006). Despite their solitary habit, octopuses have not been seen defending territories (Altman 1967, Kayes 1974, Mather and O'Dor 1991) and usually the area around a den is not defended (reviewed in Boal 2006). It seems, therefore, that octopuses in their natural environment do not hold territories and seem to be somewhat tolerant of crowding (Mather 1982), but it is equally likely that octopuses are fundamentally asocial except when ready for mating. However, studies by Huffard et al. (2010) on the intertidal octopus Abdopus aculeatus suggest that this is not always true. Further studies of social relationships in this species will help researchers to disentangle these possibilities, which again require behavioural evaluations to make behavioural assumptions.

The Rodas inlet must have more than 1000 octopus dens between 5 and $21 \mathrm{~m}$ in depth. In consequence, the Rodas inlet, which represents $1.12 \%$ of the marine realm of the Cíes archipelago, may be a preferential habitat for $O$. vulgaris individuals ranging between 200 and $2000 \mathrm{~g}$, but especially for small individuals. 
This is the first evidence of preferential habitats for $O$. vulgaris in the wild and furthers the understanding of its population dynamics within the NPAIG. This study, together with another study in preparation on where mating and brooding take place, will contribute to an effective management of the species.

Although none-invasive methods, namely visual censuses, are expensive and very time-consuming, they are ideal for enhancing the knowledge of this type.

\section{ACKNOWLEDGEMENTS}

The authors wish to thank Alex Chamorro, Francisco de la Granda (IIM, CSIC, Vigo), Enrique Poza (ECITMAT) and Pepe Castro for their valuable support in the field. We are also very grateful to the National Park authorities, José Antonio Fernández-Bouzas, Montserrat Martínez Moran and Mercedes Olmedo, as well as the Park's guards for their logistical support during the course of this study. Many thanks also to the volunteers of Ecologistas en Acción for their assistance during visual census four, and to the comments of an anonymous referee which helped to improve the original manuscript. Financial support was provided by the Organismo Autónomo de Parques Naturales de España (Ministerio de Agricultura, Alimentación y Medio Ambiente) with project 458/2011, CEFAPARQUES. Sestelo's research was supported by grant MTM201123204 (FEDER support included) from the Spanish Ministry of Science and Innovation and by grant CN2012/180 from the Galician Regional Authority (Xunta de Galicia).

\section{REFERENCES}

Álvarez-Salgado X.A., Beloso S., Nogueira E., et al. 2002. New Production of the NW Iberian shelf during the upwelling season over the period 1982-1999. Deep Sea Res. 49: 1725-1739. http://dx.doi.org/10.1016/S0967-0637(02)00094-8

Álvarez-Salgado X.A., Figueiras F.G., Pérez F.F., et al. 2003. The Portugal coastal counter current off NW Spain: new insights on its biogeochemical variability. Prog. Oceanogr. 56: 281-321. http://dx.doi.org/10.1016/S0079-6611(03)00007-7

Altman J. S. 1967. The behaviour of Octopus vulgaris in its natural habitat: a pilot study. Underwater Association Report of Malta (1966-67), pp 77-83.

Ambrose R.F. 1982. Shelter utilization by the molluscan cephalopod Octopus bimaculatus. Mar. Ecol. Prog. Ser. 7: 67-73. http://dx.doi.org/10.3354/meps007067

Anderson T.J. 1997. Habitat selection and shelter use by Octopus tetricus. Mar. Ecol. Progr. Ser. 150: 149-155. http://dx.doi.org/10.3354/meps150137

Anderson R. C., Mather J. A. 2007. The packaging problem: Bivalve prey selection and prey entry techniques of the octopus Enteroctopus dofleini. J. Comp. Psychol. 121: 300-305. http://dx.doi.org/10.1037/0735-7036.121.3.300

Anderson R.C., Wood J.B., Mather J.A. 2008. Octopus vulgaris in the Caribbean is a specializing generalist. Mar. Ecol. Progr. Ser. 371: $199-202$. http://dx.doi.org/10.3354/meps07649

Aronson R.B. 1986. Life history and den ecology of Octopus briareus Robson in a marine lake. J. Exp. Mar. Biol. Ecol. 95: 37-56.

http://dx.doi.org/10.1016/0022-0981(86)90086-9

Aronson R.B. 1991. Ecology, paleobiology and evolutionary constraints in the octopus. Bull. Mar. Sci. 49: 245-255.

Belcari P., Cuccu D., González M., et al. 2002. Distribution and abundance of Octopus vulgaris Cuvier, 1797 (Cephalopoda: Octopoda) in the Mediterranean Sea. Sci. Mar. 66: 157-166.

Boal J.G. 2006. Social recognition: a top down view of cephalopod behaviour. Vie Milieu 56: 69-79.

Boyle P.R. 1980. Home occupancy by male Octopus vulgaris in a large seawater tank. Anim. Behav. 28: 1123-1126. http://dx.doi.org/10.1016/S0003-3472(80)80101-1

Boyle P.R., Rodhouse, P. 2005. Cephalopods. Ecology and fisheries. Blackwell Science Ltd. Oxford. UK. 452 pp.

Cochrane K.L., Garcia S.M. 2009. A Fishery Manager's Guidebook. J. Wiley-Blackwell Ltd., Publications, U.K., 518 pp. http://dx.doi.org/10.1002/9781444316315

Cortez T., Castro B.G., Guerra A. 1995. Feeding dynamics of Octopus mimus (Cephalopoda, Octopodidae) from the North of Chile. Mar. Biol. 123: 497-503. http://dx.doi.org/10.1007/BF00349228

DOGA (Diario Oficial de Galicia). 2012. Orden de 27 de julio de 2012 por la que se regulan los tamaños mínimos de diversos productos pesqueros en la Comunidad Autónoma de Galicia, no 226: p. 4454.

Faraj A., Bez N. 2007. Spatial considerations for the Dakhla stock of Octopus vulgaris: indicators, patterns, and fisheries interactions. ICES J. Mar. Sci. 64: 1820-1828. http://dx.doi.org/10.1093/icesjms/fsm160

Fiorito G., Gherardi F. 1999. Prey-handling behaviour of Octopus vulgaris (Mollusca, Cephalopoda) on Bivalve preys. Behav. Proc. 6: 75-88. http://dx.doi.org/10.1016/S0376-6357(99)00020-0

Fonseca P., Campos, A. 2002. Bottom trawl cod-end selectivity for cephalopods in Portuguese continental waters. Fish. Res. 59: 263-271. http://dx.doi.org/10.1016/S0165-7836(01)00418-0

Godfrey-Smith P., Lawrence M. 2012. Long-term high-density occupation of a site by Octopus tetricus and possible site modification due to foraging behavior. Mar. Freshw. Beah. Physol. 45: 261-268

Guerra A. 1981. Spatial distribution pattern of Octopus vulgaris Cuvier. J. Zool. Lond. 195: 133-146. http://dx.doi.org/10.1111/j.1469-7998.1981.tb01897.x

Guerra A., Nixon M. 1987. Crabs and mollusc shells drilling by Octopus vulgaris (Mollusca: Cephalopoda) in the Ria de Vigo (NW Spain). J. Zool. 211: 515-523. http://dx.doi.org/10.1111/j.1469-7998.1987.tb01549.x

Hanlon R.T., Messenger J.B. 1996. Cephalopod Behaviour. Cambridge University Press, Cambridge. U.K., 232 pp.

Hanlon R.T., Conroy L.N., Forsythe J. W. 2008. Mimicry and foraging behavior of two tropical sand-flat octopus species off North Sulawesi, Indonesia. Biol. J. Linn. Soc. 93: 23-38. http://dx.doi.org/10.1111/j.1095-8312.2007.00948.x

Hartwick E.B., Thorarinsson G. 1978. Den associates of the giant Pacific octopus, Octopus dofeini (Wülker). Ophelia 17: 163-166. http://dx.doi.org/10.1080/00785326.1978.10425480

Hartwick E.B., Ambrose R.E., Robinson M.C. 1984. Dynamic of shallow-water population of Octopus dofeini. Mar. Biol. 82: 65-72. http://dx.doi.org/10.1007/BF00392764

Hermosilla C., Rocha F., Valavanis V.D. 2011. Assessing Octopus vulgaris distribution using presence-only model methods. Hydrobiologia 670: 35-47. http://dx.doi.org/10.1007/s10750-011-0671-y

Hernández-Urcera J., Garci M.E., Roura A., et al. 2014 (in press). Cannibalistic behaviour of Octopus vulgaris in the wild. J. Comp. Psycol.

Hill A.E., Hickey B.M., Shillington F.A., et al. 1998. Eastern ocean boundaries coastal segment. In: Robinson AR, Brink KH (eds), The Global Coastal Ocean, Regional Studies and Syntheses, The Sea. Vol. 11. John Wiley and Sons, Inc., New York, pp. 29-67.

Huffard C.L., Caldwell R.L., Boneka F. 2008. Mating behaviour of Abdopus aculeatus (d'Orbigny 1834) (Cephalopoda: Octopodidade) in the wild. Mar. Biol. 154: 353-362. http://dx.doi.org/10.1007/s00227-008-0930-2

Huffard C.L., Caldwell R.L. Boneka F. 2010. Male-male and malefemale aggression may influence mating associations in wild octopuses (Abdopus aculeatus). J. Comp. Psycol. 124: 38-46. http://dx.doi.org/10.1037/a0017230

Iribarne O.O. 1990. Use of shelter by the small octopus Octopus tehuelchus: availability, selection and effects on fecundity. Mar. Ecol. Progr. Ser. 66: 215-258. http://dx.doi.org/10.3354/meps066251

Iribarne O.O. 1991. Life history and distribution of the small southwestern Atlantic octopus, Octopus tehuelchus. J. Zool. Lond. 
223: $549-565$

http://dx.doi.org/10.1111/j.1469-7998.1991.tb04387.x

Katsanevakis S., Verriopoulos G. 2004a. Abundance of Octopus vulgaris on soft sediment. Sci. Mar. 68: 553-560. http://dx.doi.org/10.3989/scimar.2004.68n4553

Katsanevakis S., Verriopoulos G. 2004b. Den ecology of Octopus vulgaris Cuvier, 1797, on soft sediment: availability and types of shelter. Sci. Mar. 68: 147-157. http://dx.doi.org/10.3989/scimar.2004.68n1147

Kaiser M.J., Attrill M.J., Jennings S., et al. 2011. Marine Ecology. Processes, Systems, and Impacts. Oxford University Press, U.K. Second edition, $528 \mathrm{pp}$.

Kayes R. J. 1974. The daily activity pattern of Octopus vulgaris in a natural habitat. Mar. Behav. Physiol. 2: 337-343. http://dx.doi.org/10.1080/10236247309386935

Leite T.S. 2007. Taxonomia, distribuiçao, ecologia alimentar, pesca e opçoes de manejo de unanova espécie de polvo (Octopus insularis: Cephalopoda), no Arquipélago de Fernando de Noronha, Brasil. PhD thesis. Fundaçao Universidade Federal de Rio Grande, RS, Brasil.

Leite T.S., Haimovici M., Mather J., et al. 2009. Habitat, distribution, and abundance of the commercial octopus (Octopus insularis) in a tropical oceanic island, Brazil: Information for management of an artisanal fishery inside a marine protected area. Fish. Res. 98: 85-91. http://dx.doi.org/10.1016/j.fishres.2009.04.001

López A., Pierce G J., Valiras X.M., et al. 2004. Distribution patterns of small cetaceans in Galician waters. J. Mar. Biol. Assoc. U.K. 84: 283-294. http://dx.doi.org/10.1017/S0025315404009166h

Mangold K. 1983. Octopus vulgaris. In: Boyle P.R. (ed), Cephalopod life cycles. Vol. I. Species accounts. Academic Press, London, pp. 335-364.

Mann H.B., Whitney D.R. 1947. On a test of whether one of 2 random variables is stochastically larger than the other. Ann. Math. Stat. 1: 50-60.

http://dx.doi.org/10.1214/aoms/1177730491

Mather J.A. 1982. Factors affecting the spatial distribution of natural populations of Octopus joubini Robson. Anim. Behav. 30: 1166-1170. http://dx.doi.org/10.1016/S0003-3472(82)80207-8

Mather J.A. 1985. Behavioural interactions and captivity of captive Eledone moschata: laboratory investigations of a "social" octopus. Anim. Behav. 33: 1138-1144. http://dx.doi.org/10.1016/S0003-3472(85)80173-1

Mather J.A. 1988. Daytime activity of juvenile Octopus vulgaris in Bermuda. Malacologia 29: 69-76.

Mather J.A. 1991. Foraging, feeding and prey remains in middens of juvenile Octopus vulgaris (Mollusca: Cephalopoda). J. Zool. Lond. 224: 27-39. http://dx.doi.org/10.1111/j.1469-7998.1991.tb04786.x

Mather J.A. 1993. Octopuses as predators: implications of management. In: Okutani T., O’Dor R.K., Kubodera T. (eds), Recent Advances in Cephalopod Fisheries Biology, Vol. I. Tokai University Press, Tokyo, pp. 275-282.

Mather J.A. 1994. "Home" choice and modifications by juvenile Octopus vulgaris (Mollusca: Cephalopoda): specialized intelligence and tool use? J. Zol. Lond. 233: 359-368 http://dx.doi.org/10.1111/j.1469-7998.1994.tb05270.x

Mather J.A., Nixon M. 1990. Octopus vulgaris drills Chiton. J. Cepha. Biol. 1(2): 113-116.

Mather J.A. O'Dor R. K. 1991. Foraging strategies and predation risk shape the natural history of juvenile Octopus vulgaris. Bull. Mar. Sci. 49: 256-269.

McCullagh P., Nelder J.A. 1989. Generalized Linear Models. Monograph on Statistics and Applied Probability, 37. 2nd edition. Chapman \& Hall/CRC, $532 \mathrm{pp}$

McQuaid C.D. 1994. Feeding behaviour and selection of bivalve prey by Octopus vulgaris Cuvier. J. Exp. Mar. Biol. Ecol. 177 187-202.

http://dx.doi.org/10.1016/0022-0981(94)90236-4

Moreno A., Lourenço S., Pereira J., et al. 2014. Essential habitats for pre-recruit Octopus vulgaris along the Portuguese coast. Fish. Res. 152: 74-85.

http://dx.doi.org/10.1016/j.fishres.2013.08.005

Morisita M. 1959. Measuring of the dispersion and analysis of distribution patterns. Mem. Fac. Sci. Kyushu University, Series E, Biology 2: 771-779.

Nixon M. 1987. The diets of cephalopods. In: Boyle P.R. (ed), Cephalopod life cycles. Vol. II. Comparative reviews. Academic Press, London, pp. 201-219.

Nixon M., Boyle P.R. 1982. Hole-drilling in crustaceans by Eledone cirrhosa (Mollusca: Cephalopoda). J. Zool. Lond. 196: 439-444. http://dx.doi.org/10.1111/j.1469-7998.1982.tb03515.x

Nixon M., Maconnachie E. 1988. Drilling by Octopus vulgaris (Mollusca: Cephalopoda) in the Mediterranean. J. Zool. Lond. 216: 687-716. http://dx.doi.org/10.1111/j.1469-7998.1988.tb02466.x

Nogueira E., Pérez F.F., Ríos A.F. 1997. Seasonal Patterns and Long-term Trends in an Estuarine Upwelling Ecosystem (Ría de Vigo, NW Spain). Estuar. Coast. Mar. Sci. 44: 285-300. http://dx.doi.org/10.1006/ecss.1996.0119

Oosthuizen A., Smale M.J. 2003. Population biology of Octopus vulgaris on the temperate south-eastern coast of South Africa. J. Mar. Biol. Assoc. U.K. 85: 535-541. http://dx.doi.org/10.1017/S0025315403007458h

Ourens R., Cambié G, Carabel S., et al. 2010. Gestión pesquera, sostenibilidad y conservación de la biodiversidad en el archipiélago de las islas Cíes en el Parque Nacional de las Islas Atlánticas de Galicia (GESCIES 030/SGTB/2007/1.4). Final Report. University of Coruña, Spain, 209 pp.

Quetglas A., Alemany F., Carbonell A., et al. 1998. Biology and fishery of Octopus vulgaris Cuvier, 1797, caught by trawlers in Mallorca (Balearic Sea, Western Mediterranean). Fish. Res. 36: 237-249. http://dx.doi.org/10.1016/S0165-7836(98)00093-9

Rodríguez-Solorzano M., Devesa S., Soutullo L. 1983. Guía dos peixes de Galicia. Editorial Galaxia, Vigo, $224 \mathrm{pp}$.

Sánchez P., Obarti R. 1993. The biology and fishery of Octopus vulgaris caught with clay pots on the Spanish Mediterranean coast. In: Okutani T., O’Dor R.T., Kuboreda, T. (eds), The recent Advances in Cephalopod Fishery Biology. Tokai University Press, pp. 477-487.

Scheel D. 2002. Characteristics of habitats used by Enteroctopus dofleini in Prince William Sound and Cook Inlet, Alaska, P.S.Z.N. Mar. Ecol. 23: 185-206. http://dx.doi.org/10.1046/j.1439-0485.2002.02776.x

Scheel D., Lauster A., Vincent T.L.S. 2007. Habitat ecology of Enteroctopus dofleini from middens and live prey surveys in Prince William Sound, Alaska. In: Landman N.H., Davis R.A., Mapes R.H. (eds). Cephalopods Present and Past: New insights and fresh perspectives. Springer, Netherlands. pp. 434-458.

Spitz J., Chouvelon T., Cardinaud M., et al. 2013. Prey preferences of adult sea bass Dicentrarchus labrax in the northeastern Atlantic: implications for bycatch of common dolphin Delphinus delphis. ICES J. Mar. Sci. 70: 452-461. http://dx.doi.org/10.1093/icesjms/fss200

Tsangridis A., Sánchez P., Ioannidou, D. 2002. Exploitation patterns of Octopus vulgaris in two Mediterranean areas. Sci. Mar. 66: 59-68.

Vincent T.L., Scheel D., Hough K. 1998. Aspects of the diet and foraging behavior of Octopus dofleini in its nothermost range. Mar. Ecol. 19: 13-29. http://dx.doi.org/10.1111/j.1439-0485.1998.tb00450.x

Wilcoxon F. 1945. Individual comparisons by ranking methods. Biometrics Bull. 6: 80-83. http://dx.doi.org/10.2307/3001968

Xunta de Galicia 2006. La pesca de pulpo común con nasas en la costa gallega. Los recursos Marinos de Galicia, Serie Técnica $\mathrm{n}^{\circ}$ 6, Santiago de Compostela, $193 \mathrm{pp}$.

Zar J. H. 2010. Biostatistical analysis. 5th edition. Pearson Education, Upper Saddle River, New Jersey, 944 pp. 